\title{
A ABOLIÇÃO DA ESCRAVATURA E A EMANCIPAÇÃO DAS MULHERES NAS PÁGINAS DA REVISTA LITTERARIA ${ }^{1}$
}

\author{
THE ABOLITION OF SLAVERY AND THE EMANCIPATING OF WOMEN IN \\ THE PAGES OF REVISTA LITTERARIA
}

\section{LA ABOLICIÓN DE ESCLAVITUD Y LA EMANCIPACIÓN DE LAS MUJERES EN LAS PÁGINAS DE LA REVISTA LITTERARIA}

\author{
Aline do Amaral Garcia Strelow \\ Professora Adjunta da Faculdade \\ de Biblioteconomia e \\ Comunicação da UFRGS \\ alinestrelow@terra.com.br \\ Nádia Campos Alibio \\ Estudante de Jornalismo da \\ Faculdade de Biblioteconomia \\ e Comunicação da UFRGS \\ alibio.nadia@gmail.com
}

\section{Resumo}

Este trabalho integra o projeto de pesquisa Imprensa literária no Rio Grande do Sul no século $X I X-$ Textos e contextos ${ }^{2}$, que tem como objetivo analisar os periódicos dedicados às letras que circularam nesse estado no período, lançando o olhar para o circuito comunicacional que lhes dá vida. No presente artigo, analisamos a Revista Litteraria, folha lançada no ano de 1881. Entre os temas presentes nas páginas da publicação, estão a abolição da escravatura e a escravização da mulher. A análise tem como fundamentação teórica a História Cultural. A abordagem metodológica da pesquisa tem como base o modelo proposto por Robert Darnton para o estudo dos impressos.

Palavras-chave: História do Jornalismo; História da Imprensa; Imprensa Literária.

\footnotetext{
${ }^{1}$ Trabalho enviado ao XIV Encontro dos Grupos de Pesquisas em Comunicação, evento componente do XXXVII Congresso Brasileiro de Ciências da Comunicação (Intercom).

${ }^{2}$ Site da pesquisa: www.ufrgs.br/jornaisliterarios.
} 


\begin{abstract}
This paper is part of the research project Imprensa literária no Rio Grande do Sul no século XIX - Textos e contextos (Literary press in 19th century Rio Grande do Sul - Texts and contexts) whose purpose is to analyze literary periodicals circulating in this state at the time by looking into the communicational circuit that gives them life. In this paper we analyze Revista Litteraria, a magazine launched in 1881. The topics addressed on the publication's pages include the abolition of slavery and the enslavement of women. Cultural History provided the theoretical grounds for our analysis. Our study's methodological approach is based on the model proposed by Robert Darnton for the study of printed materials.
\end{abstract}

Key words: History of Journalism; History of the Press; Literary Newspapers.

\title{
Resumen
}

Este trabajo integra el proyecto de investigación Imprensa literária no Rio Grande do Sul no século XIX - (Prensa literaria en Rio Grande do Sul en el siglo XIX) - Textos y contextos, que tiene como objetivo analizar los periódicos dedicados a las letras que circularon en este estado en el período, lanzando la mirada para el circuito comunicacional que les da vida. En el presente artículo, analizamos la Revista Litteraria, hoja lanzada en el año de 1881. Entre los temas presentes en las páginas de la publicación, están la abolición de la esclavitud y la esclavización de la mujer. El análisis tendrá como fundamentación teórica la Historia Cultural. El abordaje metodológico de la investigación tiene como base el modelo propuesto por Robert Darnton para el estudio de los impresos.

Palabras Clave: Historia del Periodismo; Historia de la Prensa; Prensa Literaria.

Esta obra está licenciada sob uma Licença Creative Commons

\section{Introdução}

Jornais literários proliferavam-se em Porto Alegre na segunda metade do século XIX. Filiadas às mais diversas correntes, as folhas constituíam espaço privilegiado para a expressão da cultura letrada que começava a se formar. Poesias, contos, ensaios, charadas e os saborosos romances-folhetim faziam a alegria dos leitores da época e, principalmente, dos próprios escritores, que se organizavam em grupos em torno dos principais periódicos. Esses títulos compunham a vertente do jornalismo literário independente, conforme propõe Rüdiger (2003), que aparecia como uma alternativa ao jornalismo político-partidário em ascensão na Província. 
O interesse por questões relacionadas à literatura, às humanidades, ao teatro e às ciências começava a aparecer e motivava o surgimento de materiais de atualidades capazes de desenvolvê-lo. "Por outro lado, a mundialização dos horizontes de vida estava criando uma demanda por notícias, viabilizada pela extensão de várias linhas telegráficas pela Província durante a Guerra do Paraguai", explica Rüdiger (2003, p. 60), salientando que as folhas literárias e noticiosas se gestaram nesse contexto social, especializando-se progressivamente no atendimento dessas novas necessidades.

A ordem urbano-industrial nascente tinha a cidade como centro de irradiação de padrões e valores burgueses. Conforme destaca Pesavento (1999, p. 57), a cidade aparecia como o centro das operações comerciais e financeiras e também como o espaço onde se concentravam as fábricas e a massa operária. A mentalidade burguesa que emergia, conforme identifica Rüdiger (2003), favorecia a diversificação das concepções jornalísticas vigentes, propondo a supremacia de novos valores, como a veracidade noticiosa e a imparcialidade editorial. Tratava-se, acima de tudo, de uma estratégia que garantia a expansão do público potencial de cada periódico. "Em consequência disso, verifica-se a manifestação cada vez mais comum do princípio da neutralidade nos novos jornais, que visam com isso não somente se subtrair às conveniências partidárias, mas promover o 'interesse geral da sociedade"”, destaca o autor (p. 61).

Neste artigo, temos como objeto de estudo a Revista Litteraria, periódico semanal que circulou em Porto Alegre entre 1881 e 1882. Inserida no contexto acima delineado, a Revista surgiu 25 anos após o lançamento do primeiro jornal literário do Rio Grande do Sul, $O$ Guayba (1856-1858). A investigação aqui apresentada integra a pesquisa Imprensa literária no Rio Grande do Sul no século XIX - Textos e contextos, que se dedica a estudar o circuito comunicacional que envolvia os jornais literários publicados no período, contemplando, além do conteúdo das folhas, o percurso de homens e mulheres que nelas se engajaram.

\section{Porto Alegre - $\mathbf{1 8 8 0}$}




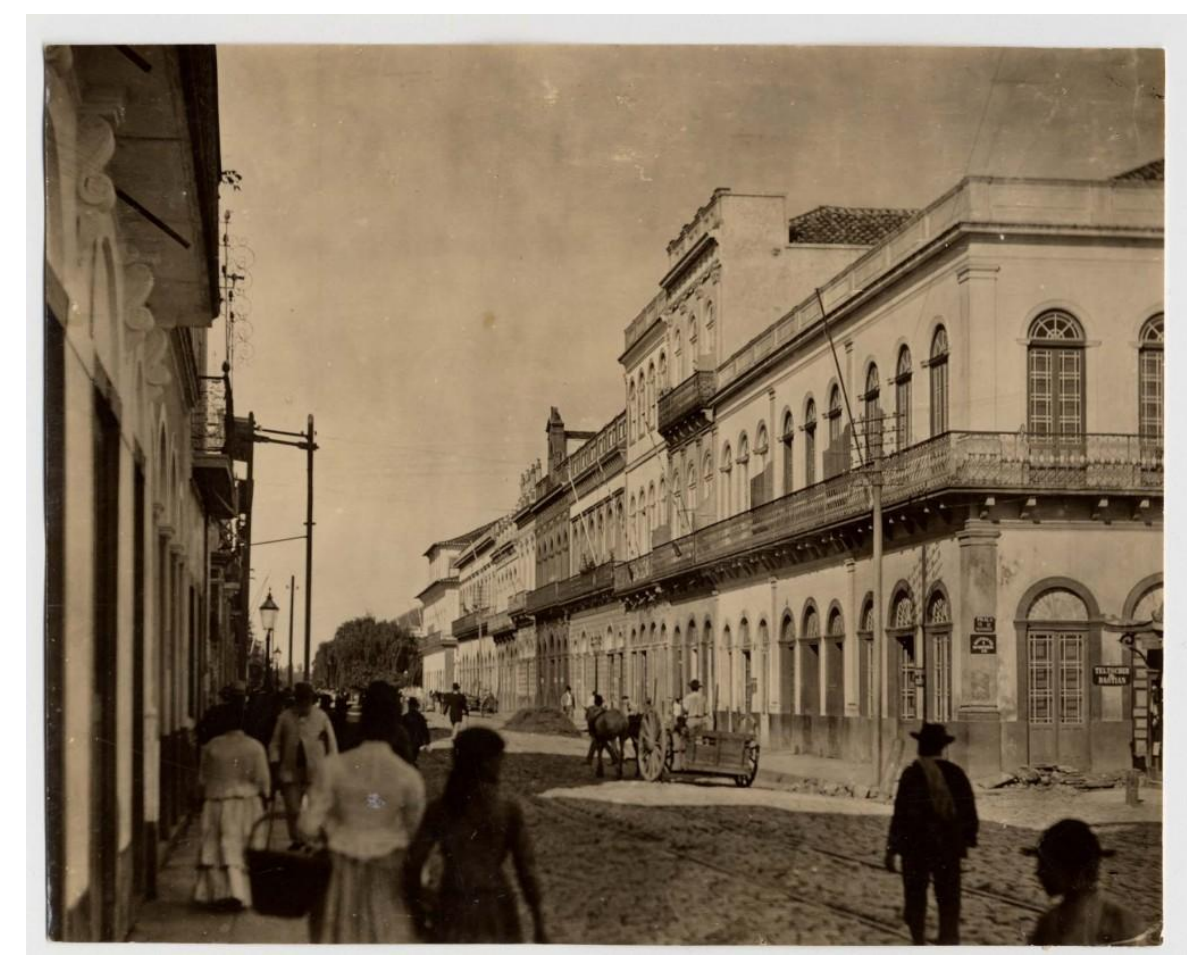

Figura 1: Esquina das Ruas 7 de setembro e Uruguai. A imagem data do início da década de 1890. Coleção Virgílio Calegari - Acervo do Museu Joaquim José Felizardo - Fototeca Sioma Breitman.

O Código de Posturas fixado em 1831, além de apontar os limites da cidade de Porto Alegre, reunia artigos relacionados a saneamento, como manter porcos em chiqueiros, criar cães daninhos, manter vasos nas janelas, correr a cavalo pelas ruas, o fechamento do comércio ao toque do sino, entre outros temas. Em relação à escravatura, conforme sublinha Macedo (1999, p. 62), estavam proibidos os castigos em lugares públicos, só sendo permitidos dentro da cadeia e não podendo exceder quarenta açoites. "Desde os primeiros números do primeiro jornal - o Diário de Porto Alegre - encontram-se notícias sobre as suas revoltas [dos escravos] e suas fugas, ao lado de anúncios para a venda deles, de diferentes idades e ambos os sexos", destaca o autor (p. 74).

A chamada Lei do Ventre Livre, de 1871, permitia ao negro, pela primeira vez, associar-se. Em Porto Alegre, foi criada a Sociedade Floresta Aurora, em funcionamento até os dias de hoje (MACEDO, 1999). Foi em meio à crise do sistema escravagista que começou a circular, na cidade, a Revista Litteraria. Sem maiores pretensões políticas e também menos afeito a disputas literárias, o periódico tinha à frente dois jornalistas negros: Paulino de Azurenha, proprietário da folha, e Aurélio Viríssimo de Bittencourt.

A cidade vivia a era dos bondes. A Companha Carris de Ferro Porto-Alegrense, de tração animal, iniciou seus serviços em 1873. O primeiro trecho da estrada de ferro que ligava a capital a São Leopoldo teve sua pedra fundamental lançada dois anos antes, em 1871 
(MACEDO, 1999). Entre as diversões públicas, destacavam-se as touradas, as corridas de cavalos, o teatro e as atividades promovidas pelas sociedades literárias. A mais importante delas foi, sem dúvida, a Sociedade Partenon Literário. Criada em 1868, reunia jovens inflamados pelo romantismo, que chegou tardiamente ao Sul. Dedicavam-se às artes literárias, mas também aos temas pulsantes da época, como a campanha abolicionista e a emancipação feminina. Publicou uma revista mensal, instituiu aulas noturnas gratuitas, organizou festivais de propaganda abolicionista, recolheu donativos para a libertação de crianças escravas, criou sua própria biblioteca e motivou a formação de outras, dedicou especial atenção ao teatro e levantou o primeiro registro das tradições e lendas locais, entre muitas outras iniciativas (CESAR, 1971). Entre seus fundadores, estava Aurélio Viríssimo de Bittencourt.

Ferreira, uma das principais referências sobre a Porto Alegre do século XIX, afirma que a imprensa literária que teve lugar no período visava à valorização do povo com o estímulo a seu gosto pelas letras, numa época em que a carência de meios de toda ordem não podia ser propícia à indústria, comércio e propagação do livro (1975). A formação de uma cultura letrada, que teve nesses jornais uma influência importante, pode ser percebida também às margens dos espaços institucionalizados pelas sociedades literárias, mas adentrando o cotidiano das famílias, como mostram os relatos sobre os saraus familiares que se tornavam cada vez mais frequentes.

No ano de lançamento da Revista Litteraria, 1881, foi aprovada a planta do primeiro chalé para bar e restaurante construído na Praça Quinze, então ainda Conde D'Eu. O espaço é um tradicional ponto de encontro da cidade até os dias de hoje. Também neste ano, foi fundado o Prado Rio-Grandense, no bairro Menino Deus, mostrando que começava a era dos hipódromos. Embora ainda modesta, aumentava a edição de livros novos. No mês de outubro, foi inaugurada a Exposição Brasileira-Alemã - a mostra industrial, agrícola e cultural era a maior das até então realizadas em Porto Alegre (FRANCO, 2012). No campo político, “em decorrência da reforma eleitoral deste ano, realizou-se em 31-out. a primeira eleição direta para o Parlamento nacional. (...) Depois da renovação do alistamento, segundo os preceitos da nova lei, que exigia renda mais elevada para eleitores, o eleitorado do município de Porto Alegre ficou reduzido a 1.687 eleitores", informa Franco (2012, p. 106).

\section{A história cultural e o circuito da comunicação}

Norteia nosso trabalho a concepção de que nossa relação com o passado se dá por meio de narrativas. Como nos ensina Barbosa (2013), construir história é fazer o movimento 
da "escrita da história". "É percebê-la como um processo complexo, no qual estão engendradas relações sociais, culturais, falas e não ditos. Compete ao historiador perguntar pelos silêncios e identificar no que não foi dito uma razão de natureza muitas vezes política", explica (p. 2-3).

Como ensina Paul Veyne (1998), a história não é apenas uma série de acontecimentos, mas a narração dessa série de acontecimentos. No projeto do qual este trabalho faz parte, nos propomos a estudar os periódicos literários que circularam na segunda metade do século XIX no Rio Grande do Sul. Pretendemos compreender os significados plurais dos textos que circulavam na sociedade da época.

Nossa pesquisa, conforme sugere Barbosa (2005), é construída em torno da questão discursiva, da produção de subjetividades, dos liames culturais e das relações de poder na sociedade. Como alerta Darnton (2010, p. 45), os jornais devem ser lidos em busca de informações a respeito de como os acontecimentos eram interpretados pelas pessoas da época, não como fontes confiáveis dos acontecimentos em si.

A abordagem metodológica da pesquisa tem como base o modelo proposto por Darnton (2010, p. 127) para o estudo dos impressos. Tal modelo parte da premissa básica de que é necessário um esforço do pesquisador para enxergar o objeto como um todo, entender o ciclo comunicacional que lhe dá vida. "As partes não adquirem seu significado completo enquanto não são relacionadas com o todo", explica (2010, p. 126). O que o autor sugere é uma análise do circuito comunicacional que envolve o objeto - ou seja, suas materialidades, os atores envolvidos e sua relação com a sociedade. "É preciso desvendar quem escrevia nesses periódicos, que estratégias esses impressos empregavam para buscar um público mais amplo - ou seja, apelos, valores e estratégias evocadas no seu discurso -, como funcionavam essas empresas e de que forma os textos chegavam ao público", esclarece Barbosa (2005, p. 104).

Para compreendermos, a partir deste modelo, a história da imprensa literária sul-riograndense do século XIX, lançamos mão de técnicas de pesquisa que são fundamentais para conseguirmos acessar os principais momentos do circuito. São elas: pesquisa bibliográfica, análise de conteúdo e pesquisa documental.

Para o estudo dos textos da Revista Litteraria, aplicamos a análise de conteúdo, conforme proposta por Bardin (1977). Catalogamos e digitalizamos todas as edições disponíveis para pesquisa no acervo do Museu de Comunicação Hipólito José da Costa ${ }^{3}$. Ao

\footnotetext{
${ }^{3}$ O Museu Hipólito José da Costa é uma instituição da Secretaria de Cultura do Estado do Rio Grande do Sul. Seu acervo de jornais reúne mais de 3 mil títulos. Ao todo, são mais de 50 mil exemplares.
} 
todo, são 320 textos, publicados em 38 edições, ao longo dos anos de 1881 e 1882 . A leitura exaustiva de todo o conteúdo da coleção foi fundamental para que pudéssemos imergir em suas teias e para que, através do cruzamento com a pesquisa bibliográfica e documental, pudéssemos realizar nossas análises. As edições digitalizadas estão disponíveis no site do projeto www.ufrgs.br/jornaisliterarios, juntamente com as coleções de outros jornais literários da época que compõem nossa investigação.

\section{Azurenha e Bittencourt: lideranças negras no período pré-abolição}

A Revista Litteraria era liderada por dois nomes importantes do jornalismo no Rio Grande do Sul, em período em que ainda iniciavam suas andanças na área. Paulino de Azurenha, proprietário, e Aurélio Viríssimo de Bittencourt, chefe de redação, participaram ativamente de publicações da época. A Revista Litteraria começou a circular em 1881, sete anos antes da abolição da escravatura no Brasil. O fato de ambos, Azurenha e Bittencourt, serem reconhecidos como homens pardos, não era um detalhe menor. Em um período em que negros e pardos estavam apartados da instrução pública, eles não apenas partilhavam, mas também eram protagonistas da cultura letrada da época.

\subsection{Oráculo das letras}

Paulino de Azurenha nasceu em Porto Alegre, em 1861. Contava 20 anos quando lançou a Revista Litteraria, tendo o amigo e padrinho de casamento Aurélio Viríssimo de Bittencourt como chefe de redação. Na mesma década, integrou a equipe do Jornal do Commercio, liderada por Aquiles Porto Alegre, em cuja gestão a folha consolidou um padrão de qualidade na imprensa gaúcha (RÜDIGER, 2003, p. 62). Em obra sobre homens ilustres do Rio Grande do Sul, Porto Alegre diz que Azurenha era considerado o melhor cronista literário rio-grandense: "Foi um herói do trabalho e deixou nome nas letras de sua terra porque, realmente, teve um alto valor" (s/d, p. 163).

Artista gráfico das oficinas do "Jornal do Comércio", quando esta folha era de minha propriedade, um dia foi Paulino de Azurenha, com maneiras tímidas, mostrar-me, no escritório, uma produção poética de sua lavra. Era um soneto. Surpreendeu-me, sobretudo, o lavor da forma, em época que tão pouco cuidado os nossos poetas do sul davam a ela. O soneto, como se sabe, 
é a "pedra de toque" por onde se conhece o quilate do poeta, e o moço tipógrafo, nessa produção, se revelava não só um poeta de mérito, como um raro, um consumado artista.

Tirei-o, pois, dos caixotins, e dei-lhe colocação mais consentânea com a sua inteligência no escritório do jornal (PORTO ALEGRE, s/d, p. 163).

Era, de acordo, com Porto Alegre, uma espécie de oráculo para os demais jornalistas todos o ouviam e obedeciam. Anos mais tarde, quando Francisco Antônio Vieira Caldas Júnior decidiu lançar o Correio do Povo, Azurenha foi o primeiro a ser lembrado. Além da intimidade com as letras, era o "homem que sabia tudo de artes gráficas" (GALVANI, 1994, p. 26). De acordo com Porto Alegre (s/d), era o único de quem Caldas Júnior aceitava conselhos e ponderações, sempre acertadas. Foi nesse jornal, como lembra o autor, que o talento de Azurenha manifestou-se em diferentes facetas. Atuou como revisor, noticiarista e repórter. Escrevia a coluna Semanário, que assinava como Leo Pardo - trocadilho bemhumorado com o nome latino do leão, a denominação de outro animal, o leopardo, e sua própria cor (GALVANI, 1994, p. 43).

Quando foi para o Correio do Povo, Azurenha já era um nome bastante conhecido e respeitado não apenas nos círculos profissionais, mas em toda comunidade. Como salienta Galvani (1994, p. 50), era um feito e tanto em uma sociedade fechada, conservadora e obviamente preconceituosa. $\mathrm{O}$ autor conta um episódio em que Caldas Júnior teria sido ríspido com um amigo que criticara a escolha por Azurenha, pois o jornal não começaria bem "com um negro em suas fileiras".

O fato de declarar-se pardo e, algumas vezes, negro em suas crônicas devia trazer-lhe riscos naquela sociedade porto-alegrense pouco afeita à aceitação das diferenças culturais e raciais vindas da comunidade negra (SANTOS, s/d). Mas a despeito dos olhares tortos e de manifestações de preconceito menos sutis, Azurenha tornou-se reconhecido na cidade por seu grande talento, chegando a integrar, em 1901, a Academia Rio-Grandense de Letras.

Em 1897, lançou, com Mário Totta e Souza Lobo, o romance Estrychnina, inspirado na história de Francisca Gama (Chiquinha) e Antônio Borges Lima (Nico). Vivendo um amor impossível, reprovado pela sociedade, o casal fez um pacto de morte e tomou estricnina. A tragédia foi explorada em minúcias pela imprensa da época e transformada em novela pelo trio de autores. Como lembra Pesavento (2006, p. 90), mal o caso encerrara, já o Correio do Povo anunciava que seus jornalistas haviam deliberado escrever um romance de atualidade, 
um livro de sensação sobre o ocorrido. Publicado pela Livraria Americana, o romance fez grande sucesso à época ${ }^{4}$.

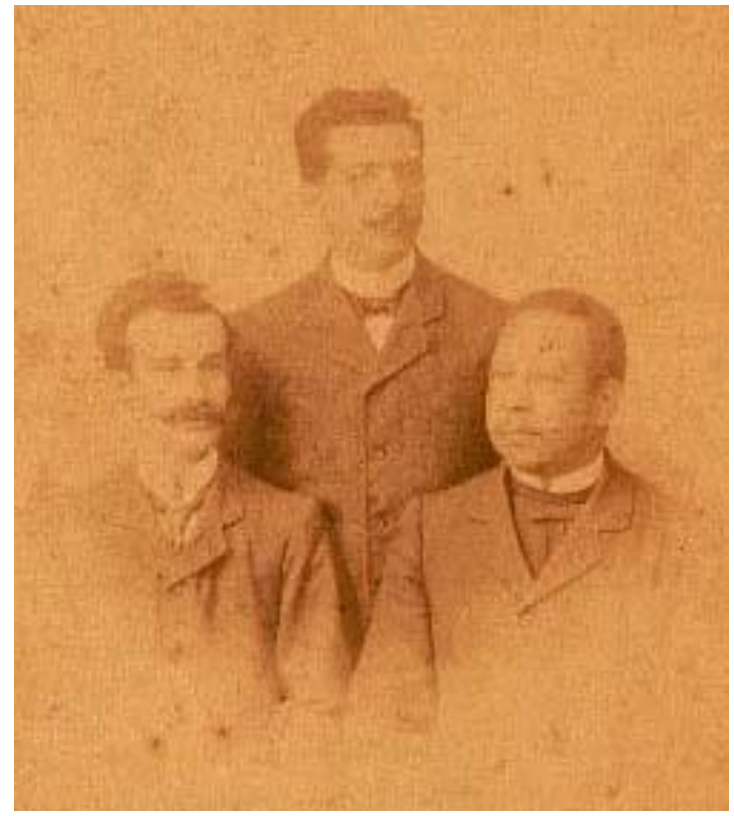

Figura 2: Da esquerda para a direita: Mário Totta, Francisco Caldas Júnior e Paulino de Azurenha, fundadores do jornal Correio do Povo 5 .

Azurenha trabalhou no Correio do Povo até sua morte, em 1909. Pelo obituário publicado no mesmo jornal ${ }^{6}$ logo após, sabemos tratar-se de um católico fervoroso e monarquista convicto. Seus tantos dotes e predicados artísticos eram realçados pela modéstia - esquivava-se de aplausos e tinha temperamento arredio, condenava-se voluntariamente a ser sempre um exilado, um solitário em meio à agitação que o rodeava. Sua influência sobre os colegas também está destacada no texto: "Paulino de Azurenha era, nesta casa, um consultor e conselheiro, a quem todos recorriam, em situações embaraçosas, para lhe pedir a opinião sempre esclarecida, e o parecer - sempre ponderado. (...) Ele a todos ouvia e a todos falava".

\footnotetext{
${ }^{4}$ Em 1997, em comemoração ao centenário da obra, foi publicada uma edição comemorativa, organizada por Luís Augusto Fischer para a editora Artes e Ofícios.

${ }^{5}$ Imagem disponível no site do Museu Júlio de Castilho:

http://museujuliodecastilhos.blogspot.com.br/2014/06/acervo-em-foco.html. Acesso em 18/07/2014.

${ }^{6}$ O obituário publicado em 1909 foi recuperado pelo departamento de pesquisa do jornal Correio do Povo e publicado na coluna Há um século no Correio do Povo. Disponível em:

http://contextopolitico.blogspot.com.br/2009/07/ha-um-seculo-no-correio-do-povo_05.html?view=snapshot.
} Acesso em 17/07/2014. 
Assim, mesmo sendo uma referência para os pares, admirado por seu talento e trabalho, optava por permanecer à margem, como um estranho naquele meio.

Ainda pelo obituário, sabemos que sua origem é humilde, mas que teve a oportunidade de dedicar-se, na meninice, ao estudo das belas letras. Terá sido aluno formal de alguma instituição de ensino? Ou terá estudado em casa, tendo como tutor algum parente letrado? Certo é que, além das belas letras, aprendeu muito cedo o ofício de tipógrafo. E foi por meio desse ofício que se iniciou nos campos do jornalismo e da literatura.

\subsection{Precursor da imprensa negra}

Aurélio Viríssimo de Bittencourt nasceu em Jaguarão, no interior do Rio Grande do Sul, em 1849, mas viveu em Porto Alegre a maior parte de sua vida. "Filho da negra Maria Júlia da Silva e do oficial da Armada Hipólito Simas de Bittencourt, ele foi batizado na Matriz local como exposto, filho de pais não conhecidos", afirma Moreira (2009, p. 1), em cuidadoso estudo biográfico do jornalista. De acordo com o autor, evidencia-se uma relação consensual entre um militar que participava da constante tarefa de vigiar a fronteira sul do Império brasileiro e uma mulher descrita nos documentos como parda.

Assim, conforme as pesquisas realizadas por Moreira (2009), Aurélio nunca foi um exposto, pelo menos não no sentido de não ter os pais ao seu lado para protegê-lo. Como a cor de seu pai não é referida nos documentos, pode se considerar que era branco ou que “embranqueceu ao avançar hierarquicamente na marinha" ${ }^{7 "}$ (p. 2). Da mãe, Aurélio herdou a cor e o status de pardo, que, como observa o autor (p. 2), o acompanhou, por vezes sendo silenciado, até o momento de sua morte.

Por volta dos 10 ou 12 anos, Aurélio foi viver em Porto Alegre, provavelmente para morar com sua tia paterna em uma casa assobradada que o pai possuía na rua General Bento Martins. Em 1861, aos 12 anos, prestou exame no Seminário São Feliciano, na capital, e foi aprovado em francês e geografia. Embora não se saiba se a relação entre Hipólito e Maria Júlia teve continuidade, ao atribuir, em documento de 1853, a propriedade da casa de Jaguarão a Maria Júlia, ele atribui a ela a chefia daquela unidade familiar (MOREIRA, 2009).

Já na capital, Aurélio trocava cartas com a mãe, que ficou em Jaguarão, doente. Tratava-se, assim, de uma família parda letrada em uma sociedade em que raros eram os alfabetizados. Aurélio, assim como Paulino de Azurenha, se insere num contexto fora dos

\footnotetext{
${ }^{7}$ Quando faleceu em 07.01.1884, Hipólito era Capitão Tenente da armada (MOREIRA, 2009, p. 2).
} 
papéis sociais padrões étnicos da sociedade da época. Sua identidade era a parda, sendo percebida como diferente nos locais onde se inseriu, sendo um não-branco, mas também percebida diferente de sua origem, como não-preto. Conforme analisa Moreira (2009), o acesso à escrita não deveria ser fácil para os não-brancos. Embora não se saiba qual sua efetividade, a lei provincial $\mathrm{n}^{\circ} 14$, de dezembro de 1837 , proibiu de frequentarem escolas públicas todos que padeciam de moléstias contagiosas, os escravos e negros, ainda que livres ou libertos. Vasculhando a documentação da Câmara Municipal de Jaguarão, o autor não encontrou referências de que Aurélio ou sua mãe tenham frequentado aulas públicas locais. Uma hipótese é que o padrinho Francisco José Vieira Valente, professor no município, tenha sido o responsável pela alfabetização de ambos.

Segundo Franco (1998, p. 73), Aurélio iniciou suas atividades profissionais como tipógrafo do jornal $O$ Mercantil, em 1864, aos 15 anos. Em 1868, ingressou no serviço público como copista da secretaria do governo da Província, onde galgou todos os postos, tornando-se Secretário da Presidência. "Nessa condição, serviu aos presidentes nomeados da monarquia, como aos presidentes do período republicano, sempre respeitado por sua experiência e ponderação”, salienta o autor (1998, p. 73). No mesmo ano de 1868, somou à atividade de copista o cargo de revisor do jornal A Reforma. No ano seguinte, além de ter sido um dos fundadores da sociedade Partenon Literário, dirigiu a revista mensal da agremiação, em sua primeira comissão de redação (FERREIRA, 1975).

Em 1875, passou a contribuir com a revista Ensaios Literários, órgão da associação de mesmo nome, criada por parte do grupo do Partenon por conta de divergências internas. Assim como a Revista Litteraria, propunha-se essencialmente literária, evitando debates de natureza política e pessoal (FERREIRA, 1975, p. 81). Aurélio colaborou ainda com os títulos Atualidade (1867), Álbum Semanal (1872) e Album de Domingo (1878).

Com documentos que indicavam tratar-se de um exposto, desejou, já adulto, em 1874, provar ser filho natural de Maria Júlia e Hipólito e o fez através de requerimento ao Juiz de Órfãos e Ausentes de Jaguarão. Em Porto Alegre, o jornalista participou de várias irmandades religiosas, entre elas a Irmandade Nossa Senhora da Conceição e a Irmandade Nossa Senhora do Rosário - ambas reuniam escravos e negros libertos.

Foi no início da década de 1880 que Aurélio Viríssimo se engajou no projeto da Revista Litteraria, nosso objeto de estudo neste trabalho e sobre a qual falaremos mais adiante. Assim como Azurenha, integrou, em 1901, a Academia Rio-grandense de Letras. Mais tarde, entre 1903 e 1911, dirigiu o Jornal do Commercio, periódico no qual Azurenha também trabalhou, mas na década anterior. 


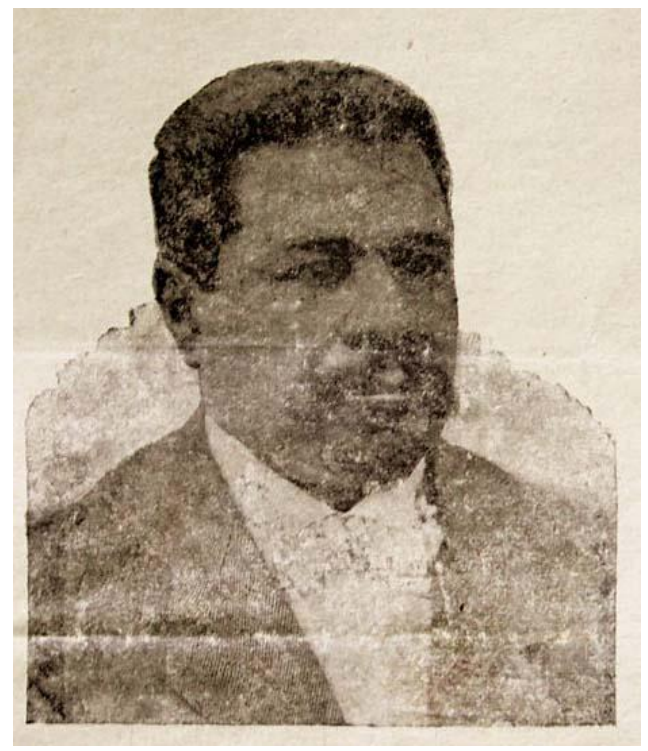

Figura 3: Aurélio Viríssimo de Bittencourt, em imagem publicada no jornal $O$ Exemplo ${ }^{8}$.

A trajetória de Aurélio serviu de inspiração para os filhos, que seguiram carreira no jornalismo e criaram aquele que seria o primeiro jornal da imprensa negra no Rio Grande do Sul: O Exemplo. Aurélio Bittencourt Júnior e Sérgio Bittencourt, ao lado de um grupo de fundadores, fizerem circular, em 12 de dezembro de 1892, o primeiro número dessa importante folha. Na fase final do periódico, entre 1920 e 1930, a direção seria confiada a Dario de Bittencourt, filho de Aurélio Júnior.

\section{Escravos e mulheres nas páginas da Revista Litteraria}

Lançada em 6 de fevereiro de 1881, a Revista Litteraria propunha-se uma publicação crítica e instrutiva. Em formato $32 \times 22$, com oito páginas, tinha periodicidade semanal. A assinatura trimestral custava $2 \$ 500$, para leitores de Porto Alegre; para o público de fora, oferecia-se uma assinatura anual no valor de 10\$000. A capa traz em destaque o nome do chefe de redação: Aurélio Viríssimo de Bittencourt. O nome do proprietário não é informado, mas assegura-nos Ferreira (1975) tratar-se de Paulino de Azurenha - que, por sinal, assina vários textos de diferentes gêneros na folha. Em nenhuma das edições é informada existência de uma redação própria; aos leitores avisava-se que a correspondência deveria ser enviada ao escritório do Jornal do Commercio, à época coordenado por Aquiles Porto Alegre e onde Azurenha também trabalhava.

\footnotetext{
${ }^{8}$ Disponível em http://pt.wikipedia.org/wiki/Aur\%C3\%A9lio_Ver\%C3\%ADssimo_de_Bittencourt. Acesso em $19 / 07 / 2014$
} 


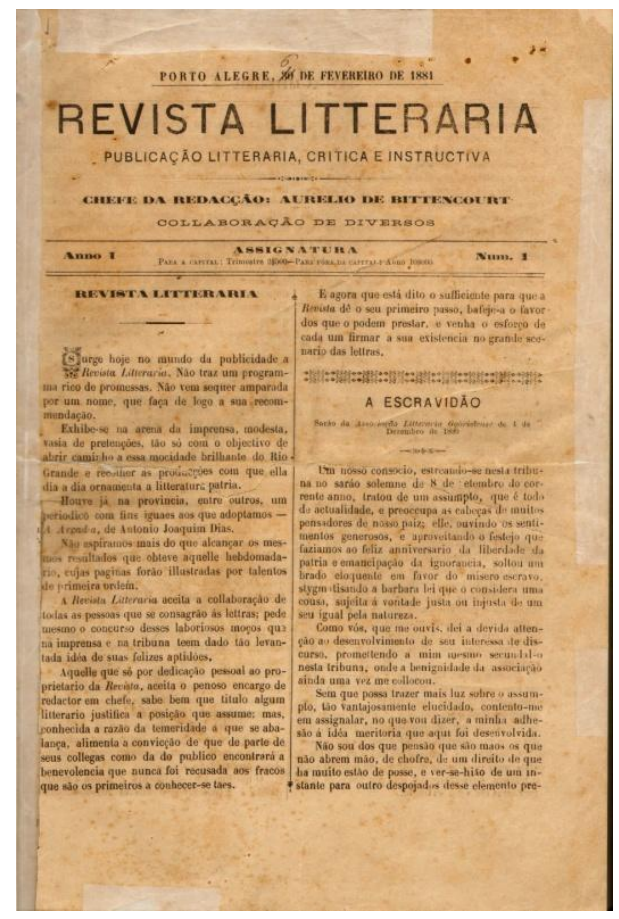

Figura 4: Capa da primeira edição da Revista Litteraria (06/02/1881).

A publicação foi bem recebida pelo público, com notas de boas-vindas divulgadas nos jornais locais. Ferreira (1975, p. 130) destaca a notícia do periódico A Reforma, no qual Bittencourt havia atuado como revisor:

Revista Literária. Com este título acaba de sair à luz mais um periódico literário e recreativo, em oito páginas, duas colunas, formato folha de papel comum. Abre carreira o novo paladino do progresso sob o auspicioso nome de Aurélio Bittencourt, primoroso cultor das letras. Saudamos o lançamento dessa revista, desejando ver coroadas de completo êxito as nobres aspirações com que se apresenta.

Considerada pelo referido autor como superior ao semanário $O$ Lábaro $^{9}$, que a antecedeu, a Revista trazia o seguinte programa:

Surge hoje no mundo da publicidade a Revista Litteraria. Não traz um programa rico de promessas. Não vem sequer amparada por um nome que faça $\log$ a sua recomendação. Exibe-se na arena da imprensa, modesta, vazia de pretensões, tão só com o objetivo de abrir caminho a essa mocidade brilhante do Rio Grande do Sul e recolher as produções com que ela dia a dia ornamenta a literatura pátria. Houve já na província, entre outros, um periódico com fins iguais aos que adotamos - A Arcádia, de Antônio Joaquim Dias. Não aspiramos mais do que alcançar os mesmos resultados

\footnotetext{
${ }^{9}$ Sobre $O$ Lábaro, ver: STRELOW, Aline; ALIBIO, Nádia. O Lábaro: a Porto Alegre do séc. XIX sob o olhar de um jornal literário positivista. Anais do 5ºncontro Regional Sul de História da Mídia - Alcar Sul 2014.
} 
que obteve aquele hebdomadário, cujas páginas foram ilustradas por talentos de primeira ordem ${ }^{10}$.

Ao apontar como referência A Arcádia, que circulou entre 1867 e 1870 nas cidades de Rio Grande e Pelotas, Aurélio Bittencourt parece antepor-se à Revista do Partenon Literário, a que intencionalmente não alude, como bem observa Ferreira (1975). Embora Bittencourt tenha sido um dos fundadores da Sociedade Partenon Literário, integrou, em 1875, o grupo que se afastou da mesma e criou a associação Ensaios Literários. Ao contrário da revista do Partenon, que se engajava em lutas sociais as mais diversas, a Revista Litteraria aproximavase da proposta da Ensaios Literários e explicitava o propósito de manter-se estritamente na esfera literária, abstendo-se de participar de outros problemas sociais e políticos da época.

No entanto, embora Ferreira (1975, p. 132) saliente que a Revista Litteria conservavase à margem da campanha abolicionista, a despeito das origens do proprietário e do chefe da redação da folha, não se pode ignorar que o tema esteve presente nas páginas da publicação, mesmo que seguramente não se possa classificá-la como uma revista abolicionista. Na capa do primeiro número, aquele em que o periódico se apresenta a seus leitores, tem destaque a publicação do artigo A escravidão, resultado da conferência de Geraldo de Faria Corrêa na Associação Literária Gabrielense (São Gabriel, RS), em dezembro de 1880:

Não podemos jamais ser um povo nobre, na expressão lata da palavra, conservando uma instituição condenada não só pela lei natural, como pela civilização.

(...)

A criatura tem coração e sente; a liberdade é a sua mais ardente aspiração, porque é ela o primeiro dos bens, diante do qual todos os outros são insignificantes, como bem disse Epíteto; com ele, os outros são desnecessários; e sem ele impossíveis.

É interessante observar que Geraldo de Faria Corrêa era antigo senhor de escravos. Apresentava-se como um homem pobre que, por dever de consciência, libertou seus dois escravos e passou a ter com eles uma relação de patrão e empregados: "Sirvo-me hoje com pessoas que me não pertencem, senão pelo dever e respeito que existe do fâmulo para quem lhe paga o salário". O texto traz uma defesa inflamada da abolição, entendida como condição para o progresso. Quer dizer, a campanha abolicionista está presente na primeira edição e também em outras do jornal, mesmo que pela voz de um homem branco que, em nome do progresso da civilização, levanta-se em favor da libertação dos escravos. O mesmo ocorreu em grande parte da imprensa abolicionista, como se sabe. À primeira vista, chama a atenção, é

\footnotetext{
${ }^{10}$ Os textos foram atualizados para o português contemporâneo.
} 
claro, que uma revista dirigida por jornalistas negros deixe a temática da escravidão para um articulista branco e, além disso, ex-senhor de escravos. Mas percebe-se aqui a busca pela legitimidade, pela identificação dos leitores - brancos, em sua maioria - com a fala daquele que escreve. Tratava-se de um igual, que abriu mão de seus escravos e afirmava não ter sido prejudicado em seus negócios por conta disso - ponto nevrálgico das discussões sobre o fim da escravidão.

Tanto Azurenha quanto Bittencourt não se colocam em momento algum como negros ou não brancos, não é isso que eles desejam como esse periódico - ambos marcariam suas posições na década seguinte: o primeiro, como o colunista Leo Pardo, no jornal Correio do Povo; o segundo, como inspirador de O Exemplo, primeiro jornal da imprensa negra do estado. De qualquer modo, mesmo que, na Revista Litteraria, tenham se dedicado predominantemente às belas letras, sem engajamento político ou social aparente, a escolha e publicação de textos relacionados à abolição e, como falaremos adiante, à emancipação da mulher, mostra o compromisso com essas questões.

Ainda sobre a escravidão, as edições 4 e 5 trazem uma crônica de Silva de Albuquerque, em que os personagens Pedro e Paulo discutem a temática da abolição, expondo diferentes opiniões a respeito do assunto. Através de Pedro, o autor tece críticas ao regime escravagista e desconstrói um a um os argumentos contrários à abolição. Mais uma vez, a temática aparece pela pena de outros articulistas, mas sua presença e o posicionamento construído através dos textos são dignos de nota.

Problemática mais explorada do que a abolição da escravatura era a emancipação das mulheres. Ferreira $(1975$, p. 137) reconhece que, se evitava intervir mais diretamente no movimento abolicionista, a Revista Litteraria dava todo seu apoio à luta contra a escravização da mulher. Artigos sobre o assunto se sucedem nas páginas da publicação. Na edição de número 6, o escritor português S. de Frias assina artigo de uma página e um quarto sobre a importância da instrução feminina. Critica as escolas que limitavam às mulheres os saberes das futilidades, que as preparavam para a falsa elegância, mas de pouca serventia eram para suas vidas. Questiona a real aplicabilidade de seus estudos, já que, fora de casa, a voz das mulheres não era ouvida, suas opiniões não tinham valor. Reivindica o lugar da mulher no mundo do trabalho, para que ela pudesse dispor de um ofício, cargo, ciência, profissão, "uma ocupação qualquer que estabeleça à volta de si a autonomia, concedida a qualquer pessoa pelas leis salutares do trabalho".

Em “A mulher e a sociedade”, publicado na edição 8, J. M. Latino Coelho vocifera que a mulher não veio ao mundo para oscilar, qual um pêndulo, entre o amor e o crochê, entre 
a modista e o toucador. "Enfeitem o cabelo ao toucador, mas exornem também o cérebro na escola", diz. O autor denuncia que, mesmo tendo melhorado a situação da mulher no trato doméstico e social, pouco mudou em relação à sua emancipação política e à sua participação como elemento de influência legal no destino das nações. Certamente essa luta pela libertação da mulher estava imersa no pensamento da época, como fica claro no texto de Teixeira de Vasconcellos, publicado no número 27, sob o título $O$ homem e a mulher: "Ao homem, a missão de fundir, nos moldes preparados pelo espírito nacional a formosa estátua da civilização; à mulher, o suave encargo de limar as asperezas da fundição, de aperfeiçoar e completar a obra do homem". Trata-se, assim, de um discurso impregnado pelo ideário positivista, em que a instrução feminina aparece como garantidora da ordem, sendo a mulher a grande educadora da casa e, por consequência, da sociedade. Esse viés não diminui a importância desses textos e de sua circulação, eles integravam uma visão de mundo da época e a linguagem proposta àqueles que se propunham a contá-la.

Se as questões relacionadas à mulher eram abordadas predominantemente por homens, não significa que elas também não colaborassem com a revista. Ana Aurora do Amaral Lisboa, Carlota do Amaral Lisboa, Julieta Monteiro e Revocata de Melo também tiveram seus textos ali publicados. Sobre Julieta e Revocata, é importante lembrar que foram as fundadoras do jornal feminino O Corimbo, periódico que circulou de 1883 a 1943, editado no município de Rio Grande, onde ambas residiam.

Destacamos ambas as temáticas para análise nesse texto, embora outros assuntos tenham conquistado espaço nas páginas da Revista Litteraria, como as eleições diretas para o parlamento nacional, a Exposição Brasileira-Alemã e a vida cultural da cidade - as peças de teatro, o carnaval, as corridas de cavalo, o vai e vem dos bondes. Através da leitura exaustiva da coleção, conseguimos identificar os vestígios de jornalistas e escritores que nela se engajaram, mas também de seus leitores. Um dos espaços para esse encontro era a seção Expediente, publicada ao final de cada número, onde eram divulgados os títulos de jornais e revistas recebidos pela redação e enviados recados para leitores e assinantes. Na maioria deles, encontramos respostas a textos literários enviados para publicação na revista - algumas delas agradecendo e informando o aproveitamento do material naquela mesma edição, outras postergando a publicação para um próximo número, por falta de espaço, e outras ainda trazendo breves críticas às produções enviadas, consideradas de baixa qualidade e por isso não aproveitadas. Exemplo dessas respostas aos leitores é a seguinte nota publicada na referida coluna: "Ao Sr. Timotheo de Faria - A sua poesia, deve tê-la visto adiante. Quanto ao seu apresentado, sentimos não poder dizer o mesmo. Correta, volte". Percebemos, assim, 
tratar-se de um público que lê, mas também escreve. Que acompanha o cenário literário local e deseja dele participar. Também aparecem nesse espaço correspondências recebidas de outros jornais e também enviadas a eles. Os jornalistas das diversas folhas literárias e noticiosas da época liam uns aos outros, o que não é novidade - a diferença é que, naquele momento, essas apreciações eram verbalizadas e muitas vezes fixadas nas páginas dos jornais, mesmo que para isso fosse preciso elogiar ou criticar a concorrência.

\section{Referências}

BARBOSA, Marialva. Jornalismo impresso e a construção de uma memória para a sua história. In BRAGANÇA, Aníbal; MOREIRA, Sônia Virgínia (org.). Comunicação, acontecimento e memória. São Paulo: Intercom, 2005.

. Meios de comunicação e história: um universo de possíveis. In RIBEIRO, Ana Paula Goulart; FERREIRA, Lucia Maria Alves. Mídia e memória: A produção de sentidos. Rio de Janeiro: Mauad X, 2007.

Por uma história cultural da imprensa. In Alceu - Revista do Programa de PósGraduação em Comunicação da Universidade Federal de Juiz de Fora (UFJF). Vol. 2, nº 1, Julho de 2008.

Múltiplas formas de contar uma história. In Alceu - Revista do Departamento de Comunicação Social da Pontifícia Universidade Católica do Rio de Janeiro (PUC-RIO). Vol. 10, $\mathrm{n}^{\mathrm{o}} .20$, Janeiro a Julho de 2010.

BARDIN, Laurence. Análise de conteúdo. Lisboa: 70, 1977.

CESAR, Guilhermino. História da literatura do Rio Grande do Sul: 1737_1902. Porto Alegre: Globo, 1971.

DAMASCENO FERREIRA, Athos. Imprensa literária de Porto Alegre no século XIX. Porto Alegre: UFRGS, 1975.

. O carnaval porto-alegrense no século XIX. Porto Alegre: Livraria do Globo, 1970.

DARNTON, Robert. O beijo de Lamourette: Mídia, cultura e revolução. São Paulo:

Companhia das Letras, 1995.

FRANCO, Sérgio da Costa. Gente e espaços de Porto Alegre. Porto Alegre: Ed. da Universidade/UFRGS, 2000.

Porto Alegre: Ano a ano - Uma cronologia histórica 1732-1950. Porto Alegre: Letra \& Vida, 2012.

GALVANI, Walter. Um século de poder: Os bastidores da Caldas Júnior. Porto Alegre: Mercado Aberto, 1994. 
MACEDO, Francisco Riopardense de. História de Porto Alegre. Porto Alegre: Editora da Universidade/UFRGS, 1999.

MOREIRA, Paulo Roberto Staudt. Uma Parda Infância: Nascimento, primeiras letras e outras vivências de uma criança negra numa vila fronteiriça (Aurélio Viríssimo de Bittencourt / Jaguarão, século XIX). Anais do $4^{\circ}$ Encontro Escravidão e Liberdade no Brasil Meridional. 2009. Disponível em:

http://www.escravidaoeliberdade.com.br/site/images/Textos4/paulomoreira.pdf. Acesso em: 19/07/2014.

PESAVENTO, Sandra Jatahy. Fronteiras da desordem: violência e sensibilidade do sul do Brasil, final do século XIX. In: Sociabilidades, justiças e violências: práticas e representações culturais no Cone Sul (séculos XIX e XX). Porto Alegre: UFRGS, 2008. . Exposições Universais, espetáculos da modernidade do século XIX. São Paulo: Hucitec, 1997.

PORTO ALEGRE, Aquiles. Homens ilustres do Rio Grande do Sul. Porto Alegre: Erus, s/d. . Memória Porto Alegre - Espaços e vivências. Porto Alegre: UFRGS, 1999.

. Morrer de amor: o suicídio - da escrita do eu ao romance urbano. In LOPES, Antonio Herculano; VELLOSO, Monica; PESAVENTO, Sandra Jatahy. História e linguagens: Texto, imagem, oralidade e representações. Rio de Janeiro: 7Letras, 2006.

RÜDIGER, Francisco. Tendências do jornalismo. Porto Alegre: UFRGS, 2003.

SANTOS, José Antônio. O Curriculum Vitae como vestígio do passado. Dario de Bittencourt (1901-1974), uma eminência duplamente parda. Anais do IX Encontro Nacional de História. Disponível em: http://eeh2008.anpuhrs.org.br/resources/content/anais/1212439744_ARQUIVO_DARIODEBITTENCOURT.pdf. Acesso em 19/07/2014.

VEYNE, Paul. Como se escreve a história. Brasília: UNB, 1998. 
Original recebido em: 09/03/2015

Aceito para publicação em: 30/07/2015

Aline do Amaral Garcia

Professora Adjunta da Faculdade de Biblioteconomia e Comunicação da Universidade Federal do Rio Grande do Sul (UFRGS). Realizou pós-doutorado em Comunicação pela Universidade Metodista de São Paulo (UMESP). Doutora e Mestre em Comunicação pela Pontifícia Universidade Católica do Rio

Grande do Sul (PUCRS). Coordenadora do Grupo de Pesquisa em História da Comunicação da Fabico/UFRGS.

Nádia Campos Alibio Graduanda em Jornalismo na Faculdade de Biblioteconomia e Comunicação da UFRGS 